\title{
ASSESSMENT OF STRATEGIC MARKETING PLANNING
}

\author{
E. Genchev* \\ Faculty of Economics, Trakia University, Stara Zagora, Bulgaria
}

\begin{abstract}
The planning of marketing activities is one of the main priority of the company. The main task of the author is based on literature review to apply the tool for evaluating marketing planning. On the one hand, this will reveal weaknesses in marketing planning. On the other hand will enable search of additional resources to improve the company's activities.

After research and analysis of the data we come to the following conclusions:

- $\quad$ marketing planning does not apply in most of the surveyed companies ;

- $\quad$ lack basic analytical techniques to assess the level of marketing planning;

- in today's dynamic environment, it is absolutely necessary to use modern management techniques and software to support decision-making in marketing planning. We note that the software are quite affordable, easy to use and will quickly increase corporate efficiency.
\end{abstract}

Key words: marketing planning, strategic, assessment, frim management

\section{INTRODUCTION}

In the current market conditions and the global economy perception of marketing management approach becomes crucial for Bulgarian industrial enterprises.

The main purpose of this article is to analyze the level of marketing planning of a sample of companies in Stara Zagora region. The implementation of the goal requires the implementation of several main tasks: - to explore the basic theoretical and methodological characteristics of marketing planning;

- to develop an instrument for assessing marketing planning - to evaluate the marketing planning in a sample of companies in Stara Zagora region and to reveal problem areas that hinder its use.

We will first look at some definitions of marketing planning, by leading specialists in this field.

According Westwood marketing planning is used to describe the methods of applying marketing resources to achieve marketing objectives [1]. Marketing planning as defined by Marian Wood is the structured process of researching and analysing the marketing

* Correspondence to: Evgeni Genchev, Faculty of Economics, Trakia University, Stara Zagora, Bulgaria,evg_gen2000@abv.bg situation; developing and documenting marketing objectives, strategies and programs; and implementing, evaluating and controlling activities to achieve quantifiable and measurable objectives. [2].

According to Malcolm MacDonald [3] the purpose of market planning is to identify and create a competitive advantage, it is the planned application of marketing resources to achieve marketing objectives.

Some Bulgarian authors also contribute in this direction. According Mladenova "marketing planning broadly represents management process covering the analysis, definition of marketing object, target marketing, formulation, evaluation and selection of marketing strategy, resulting in the organization reach its corporate objectives based on developing and maintaining a strategic fit between organizational capabilities of one hand, and the threats and opportunities arising in a changing environment, on the other. [4]

Marketing planning is critical for a company as it evaluates the company, gives directions and guidance, and enables to set objectives and to identify alternatives and strategies.

Small businesses are often owned and operated simultaneously by their owners who take strategic decisions based more on intuition than on academic principles [5]. 
The main aspects of marketing planning in Bulgarian companies are considered by Hristov [6]

\section{METHODOLOGY}

The subject of the research is twelve companies from Stara Zagora region. The survey covered enterprises of the three sectors of the economy - manufacturing, trade and services ". The firms differ in their legal status, size and style of management.

Our sample is structured in a way so that it approximates the distribution of firms by sector [7]. Total respondents - 12 companies in the following sectors:

" Manufacturing " - 16.7\% ;

"Trade" - 33.3\%

"Services" 50\%

The object of study is assessing the implementation of marketing planning of

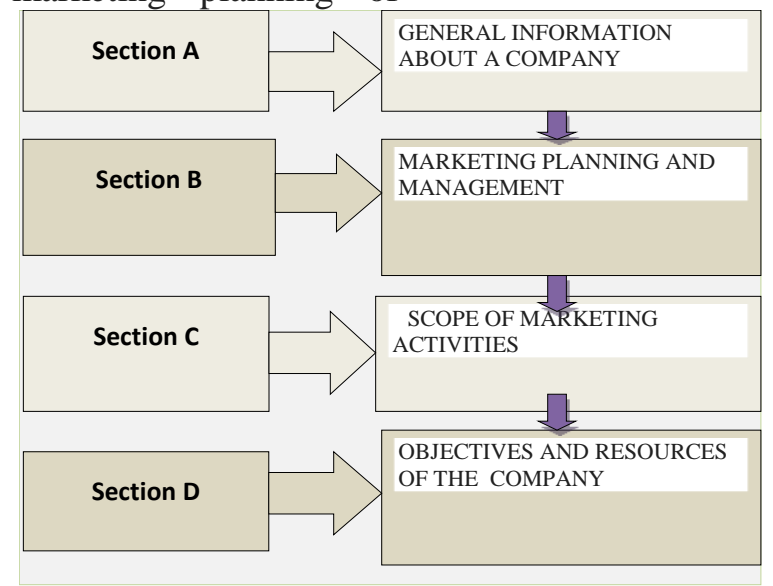

Figure 1. Sections of the questionnaire

\section{RESULTS AND DISCUSSION}

In the section " Marketing planning and management " were analyzed levels of marketing planning, its importance and the involvement of senior management in this activity.

It was found that a very high percentage - 33\% economic units as a set of approaches and fields of application stages on the one hand, and the discovery of some factors that impede its implementation by the other.

The main research hypothesis is that firms in the economy do not know very well the specifics of marketing planning and do not have fully adequate resources that would foster its wider use.

The main tool used to achieve the objective of the study is survey. In terms of content, structure and the proposed survey is a tool for testing and evaluating the implementation of marketing planning in the activities of the companies surveyed.

Itself questionnaire includes a number of questions, structured in groups and divided into four main sections (Figure 1). of surveyed companies do not develop a

marketing plan , although $50 \%$ of them confirmed that marketing is an important part of their business planning.

The degree of involvement of senior management in the implementation of marketing planning situation is as follows:

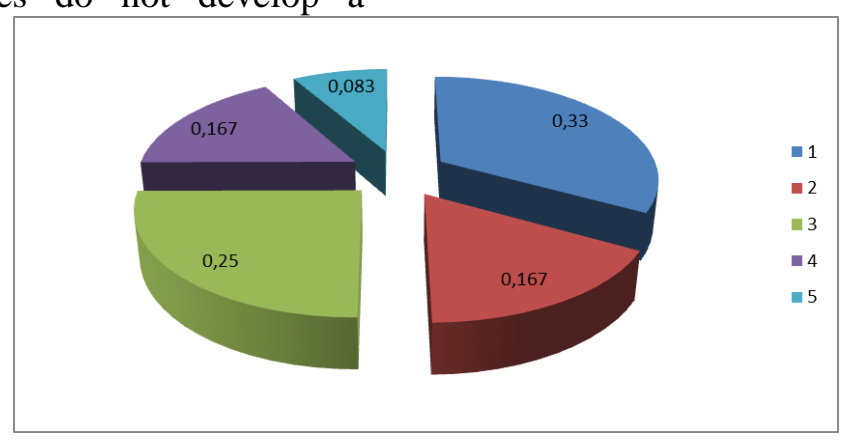

Figure 2. Degree of involvement of senior management in marketing planning

Legend:

Almost Always True

- Usually True

- Sometimes But Infrequently True

- Usually Not True

- Almost Never True 
Section " Scope of marketing activities "

Let's look at the main scope of marketing planning. For better visibility, we have divided the given evaluation of the companies in the sample of the possible maximum score . Thus, as a corporate activity is closer to one or the maximum score - the more efforts are made in this direction.
Most companies give high marks to the level of knowledge of its customers - 52\%, followed by the implementation of market segmentation - $33 \%$ and analysis of external and internal environment - 31\%." Achilles heel " of the surveyed companies remain market research, with only $27 \%$ of the maximum score - see Figure 3

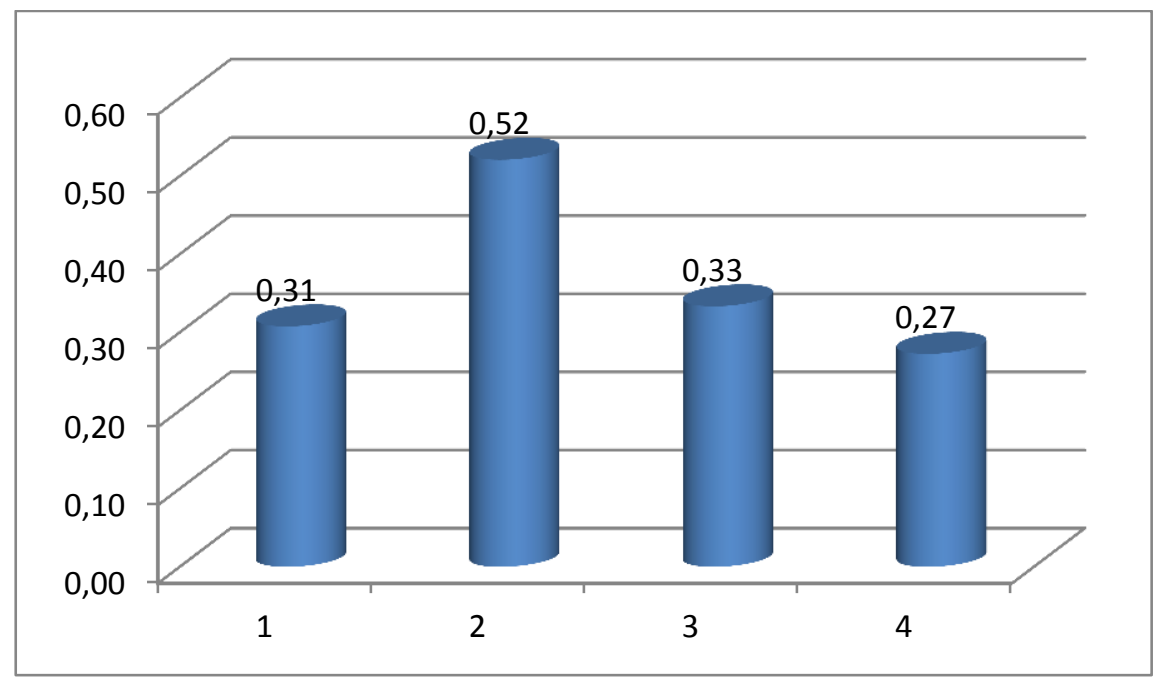

Legend:

Figure 3. Scope of marketing planning

1.The company systematically analyzes the internal and external environment 2. The company knows its customers and consumers 3. The company carries out market segmentation 4. The company conducts market research

We should be noted that without good knowledge of the market, through systematic market research, marketing planning is not particularly effective. Generally the three main aspects: environment analysis, market segmentation and market research received only about $30 \%$ of maximum levels.
Only $16.7 \%$ of companies evaluated in the planning market research fully and largely true, and some $58 \%$ define it as average and unsatisfactory.

Let's look at what the companies give importance to individual elements of the marketing mix, see Figure 4

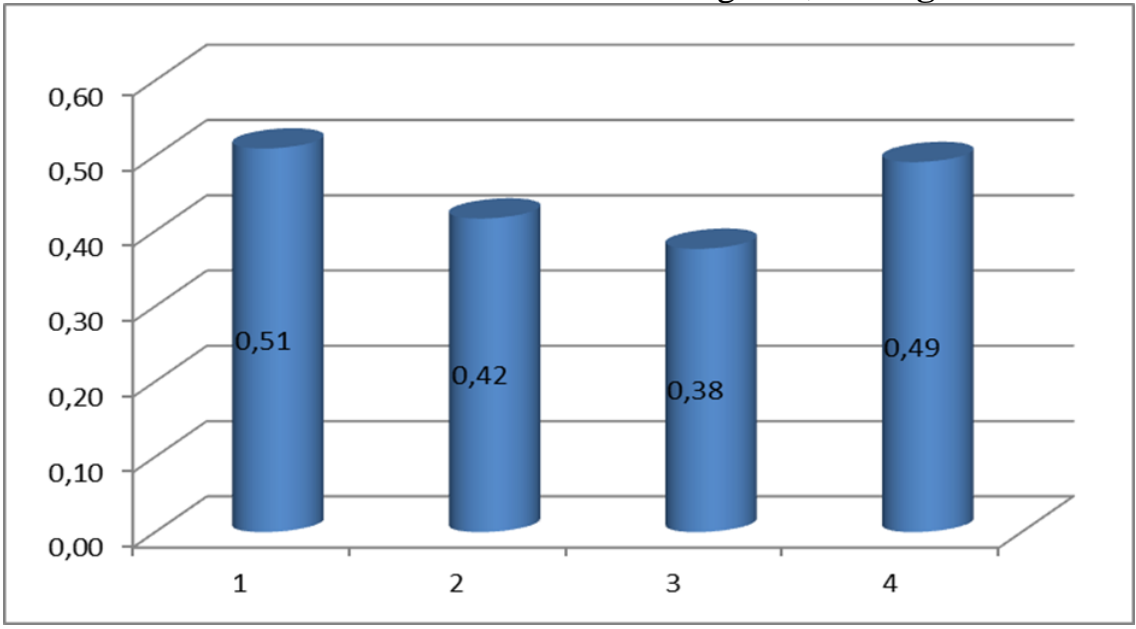

Figure 4. Research on the planning of the elements of marketing mix-product, price, distribution and communication politics

Legend:
1. Product policy

2. Pricing Policy

3. Distribution Policy

4. Communication Policy 
The companies give the product planning policy the highest score equal to $51 \%$ of the maximum, followed by communication policy by $49 \%$. The pricing policy is in third place with $42 \%$, which is surprising in companies operating in conditions of low demand in the market. The weakest element of the marketing mix is the distribution by $38 \%$.

Section „Objectives and resources of the company"

In today's dynamic environment the lack of developed and adopted a system of quantitative and qualitative indicators can affect very negatively the activities of the company. What are the main corporate objectives to be pursued by companies?

The distributi on goals:

- Pursuit of profit: $41.6 \%$ of the firms respond "almost always true" and 50\% of them respond "usually true"

- Pursuit of revenues from sales: $50 \%$ of the firms respond "almost always true" and $25 \%$ of them respond "usually true".

Market metrics that are associated with very good knowledge of competitors and average industry profitability are not popular. Only 25 $\%$ of companies interested in market share and average industry profitability in the industry.

About $42 \%$ of companies believe that to a large extent be able to react to changes in the environment, but the other $25 \%$ are those who do not have the resources for an adequate response. The problems for this are many but we will only highlight two: First, corporate budgets are not consistent with the objectives. Second, companies do not have any software to support decision making. Besides accounting programs that are used for reporting income and expenses, only $50 \%$ of companies possess and software for movement of material and inventory. In our highly information society - the lack of software used in marketing planning is a big problem and it should be given enough attention.

\section{CONCLUSION AND RECOMMENDATIONS}

Managers of companies should understand the nature and content of marketing planning as a continuous process of learning with its inherent methodological apparatus of approaches, principles, methods, rules, procedures.

It is a shift from the so-called internal company focus to the achievements of rivals such as market share, profitability in the sector and others.

\section{REFERENCES}

1. Westwood, John, "The marketing plan: a step-by-step guide", London : Kogan Page 2002 3rd ed., p.12

2. Woods, M.B. (2003), The Marketing Plan. A Handbook. New Jersey: Prentice-Hall.

3. McDonald M. Marketing planning understanding marketing plans and strategy, Kogan Page, 2008

4. Mladenova, The Marketing Planning , University Publishing House " Economy ", Sofia, 2006

5. Ennis, S. (1998). "Marketing Planning in the Smaller Evolving Firm: Empirical Evidence and Reflections." Irish Marketing Review 11(2): 49-61.

6. Hristov, H. "Nature and characteristics of marketing planning" ,Economics alternatives, vol.6, 2011

7. Economic Yearbook, Stara Zagora, 2014 